\title{
Prevalence of protein energy malnutrition in HIV-infected under five children and the effects of highly active antiretroviral therapy on their nutritional status in Nigeria
}

\author{
Sylvia T Echendu 1, Kenneth N Okeke 1,2, ${ }^{*}$, Joy C Ebenebe 1,2, Ebelechuku F Ugochukwu 1,2, Chinyere U \\ Onubogu 1, 2, Esther N Umeadi 1, 2, Ifeoma Egbuonu 2, Emeka S Edokwe 1, 2, Christian C Ifezulike ${ }^{3}$, and George \\ U Eleje ${ }^{4}$ \\ ${ }^{1}$ Department of Pediatrics, Nnamdi Azikiwe University Teaching Hospital, Nnewi, Nigeria. \\ ${ }^{2}$ Department of Paediatrics, Nnamdi Azikiwe University, Awka, Nigeria. \\ ${ }^{3}$ Department of Paediatrics, Chukwuemeka Odumegwu Ojukwu University Teaching Hospital, Amaku-Awka, Anambra \\ State, Nigeria. \\ ${ }^{4}$ Department of Obstetrics and Gynaecology, Nnamdi Azikiwe University, Awka, Nigeria.
}

Magna Scientia Advanced Research and Reviews, 2021, 01(03), 053-061

Publication history: Received on 02 February 2021; revised on 08 March 2021; accepted on 10 March 2021

Article DOI: https://doi.org/10.30574/msarr.2021.1.3.0024

\begin{abstract}
Aim: To determine the prevalence of malnutrition among HIV- infected under-five children and effect of highly active antiretroviral therapy (HAART) on the nutritional status.

Method: This cross-sectional and descriptive study was conducted among under-fives presenting at the Paediatric HIV clinic in a tertiary centre in Nigeria. HIV positive children aged less than five years, who were on HAART and whose parents/caregivers gave consent were included. Odds ratios (ORs) and their 95\% confidence intervals (CIs) were determined in a multivariate logistic regression analysis and p-values of $<0.05$ were considered significant.
\end{abstract}

Result: A total of 92 HIV positive children comprising 52 (56.5\%) males and 40 (43.5\%) females were recruited, giving a ratio of 1.3:1. Children who were more than 48 months of age were (46.7\%), while (9.8\%) were aged 24 months or less. The mean age of the children was $44.5 \pm 12.9$ months, while that of the male and female children were $43.9 \pm 13.1$ months and 45.2 \pm 12.6 months, respectively, and their age difference was statistically insignificant.

The prevalence of undernutrition was $40.2 \%$ with a significantly higher proportion of them being male children $(\mathrm{P}=$ 0.02 ) while $1.1 \%$ of the children was overweight. The prevalence of severe wasting, severe underweight and severe stunting were $2.1,3.3$ and $17.4 \%$ respectively. A total of 12 (13.0\%) were wasted, 14 (15.2\%) were underweight, and $26(28.3 \%)$ were stunted. Children who received HAART for more than 12 months were less likely to be wasted $(\mathrm{P}=0.02)$. Multivariate logistic regression also showed that being a male increased the risk of being underweight $(\mathrm{OR}=2.55,95 \% \mathrm{CL}=1.06-6.16)$ and stunted $(\mathrm{OR}=2.67,95 \% \mathrm{CL}=1.32-5.40)$.

Conclusion: Malnutrition remains a problem of children living with HIV even while they are on HAART. The longer duration of HAART is significantly associated with better nutritional status.

Keywords: Malnutrition; HIV-Infected; Children; Antiretroviral; Nutritional.

\footnotetext{
${ }^{*}$ Corresponding author: Kenneth N Okeke

Department of Paediatrics, Nnamdi Azikiwe University, Awka ,Nigeria.

Copyright (@ 2021 Author(s) retain the copyright of this article. This article is published under the terms of the Creative Commons Attribution Liscense 4.0.
} 


\section{Introduction}

Protein Energy Malnutrition (PEM) is a nutritional problem that results from varying proportions of protein and calorie deficiency in infants and young children [1]. It is a global public health challenge that affects several parts of the world [2]. It has been identified by the World Health Organization (WHO) as the most lethal form of malnutrition, causing annual deaths of at least 10.8 million under-five children in developing countries [3]. Estimates from 2003-2013 Nigeria National Demographic and Health Survey (NDHS) gave a stunting rate of $41 \%$, while underweight and wasting was estimated to be $23 \%$ and $14 \%$ respectively [4]. Malnutrition is rife even in the study area, as a survey of preschool children carried out several years earlier yielded a wasting rate of $21 \%$ [5].

Though some gains have been made in reducing childhood malnutrition by the improvement in child survival strategies through breastfeeding, immunization, use of oral rehydration therapy (ORT) in the management of diarrheal diseases, millions of children are still malnourished [4]. In Sub-Saharan Africa (SSA), providing sufficient food and nutrition to meet basic needs for health, growth and development of children has been a longstanding challenge [6]. This is further exacerbated by the emergence of the Human Immune Deficiency Virus/Acquired Immune Deficiency Syndrome (HIV/AIDS)[6,7]. The HIV pandemic has weakened the socioeconomic status in Africa, making it even more difficult to ensure food security, education and other essential services. It has also caused a dramatic increase in the mortality rates of infants and children due to AIDS-related deaths [8]. HIV-positive children are prone to malnutrition due to inadequate intake of food, nutritional loss, metabolic changes and increased requirements for both macro and micronutrients.

The effect of HIV on nutrition begins early in the course of the disease even before it becomes evident that the child is infected [9]. Energy requirement is likely to increase by $10 \%$ to maintain body weight, physical activity and growth in asymptomatic children and for this reason, energy intake needs to be increased by $50-100 \%$ over standard requirements in children experiencing weight loss in HIV [6].

Achieving the Sustainable Development Goal (SDG) that aims to reduce malnutrition and childhood mortality depends partly on the ability of the government and policy makers to address the nutritional needs of the children especially those living with HIV/AIDS in hyper endemic areas $[10,11]$. The critical role of nutritional support in the survival of HIV-infected individuals is well known $[12,13]$. Nutritional support is recommended as part of the care provided for HIV-positive children in developing countries such as Nigeria [14]. This is jeopardized by stigmatization and discrimination, ultimately contributing to reduced food availability and insufficient dietary intake for these patients.

Healthcare cost for laboratory investigations and antiretroviral (ARV) drugs further worsen the economic status of the affected families resulting in impoverishment [15].

This study seeks to determine prevalence of malnutrition in HIV infected children and the relationship between the nutritional status of these HIV/AIDS under-five children and duration on HAART. The findings of this study may help strengthen the support system targeted at these children.

\section{Material and methods}

\subsection{The study site}

This study was a cross-sectional descriptive study conducted in the Paediatric HIV Clinic of Nnamdi Azikiwe University Teaching Hospital Nnewi (NAUTH), Nnewi, Anambra State, Nigeria. NAUTH is a tertiary health institution in Anambra State, South East (S.E.) Nigeria. The hospital maintains a Paediatric HIV Clinic which runs daily from 8am to $4 \mathrm{pm}$ and is run by three Consultant Paediatricians, three senior Registrars, three Medical officers, five nurses, one adherence counsellor and a dietician.

\subsection{The Study Participants and Recruitment.}

Ninety-two confirmed HIV positive children aged less than five years, who were on HAART and whose parents/caregivers gave consent were recruited for the study. Convenient sampling was done.

\subsection{Ethical approval}

Ethical approval for the study was obtained from the Ethics committee of Nnamdi Azikiwe University Teaching Hospital, Nnewi South East Nigeria (NAUTH/CS/VOL.3/100). Written informed consent was obtained from caregivers before enrolling the selected subjects into the study. The caregivers were educated on the general nature of the research, the 
possible study benefits and the role the result of the research may play in improving the management of the patients. Participation was voluntary, and no penalty was borne by those who declined inclusion.

Subjects who met the inclusion criteria were recruited consecutively as they presented to the HIV clinic until the sample size was attained.

\subsection{The Study procedures}

For children aged more than two years, height was measured with the subject standing. The two legs were together and in full extension with the heels, buttocks, shoulder blade and occiput in firm contact with the measuring rule. Readings were recorded to the nearest $0.5 \mathrm{~cm}$ using a stadiometer. (Health scale model, RGZ - 120).

The children were weighed with minimal clothing using Health scale model RGZ - 120. Each day, the weighing scale was validated using a standard weight of $20 \mathrm{~kg}$. The reading was recorded to the nearest $0.1 \mathrm{~kg}$.

For children less than two years, the recumbent length was measured using an infantometer placed on a firm surface with an assistant, usually the mother. The knees were held down, and the head held firmly against the headboard. The measurement was taken to the nearest $0.1 \mathrm{~cm}$.

Infant aged less than two years were weighed completely naked using a $20 \mathrm{~kg}$ infant Health Scale model RGZ - 120 to the nearest $0.1 \mathrm{~kg}$. The measurements were read at eye level (in a squatting position) to avoid the error of parallax. The weighing scale was cross-checked for zero adjustments before another baby was weighed.

Social class was determined using the socioeconomic indices of the parents as described in the literature. ${ }^{16}$

The exact day HAART was commenced, and the Clinical Staging of the subjects was obtained from their medical records which are being updated from time to time by the Paediatric Infectious Diseases unit.

Furthermore, the percentile scores for height-for-age, weight-for-height, and weight-for-age were computed using the World Health Organization Anthro Software for calculating Paediatric anthropometry and compared with that of reference population from WHO-NCHS as a measure of the children's nutritional status.

\subsection{Data Analysis}

Data were analyzed using SPSS (Statistical Package for Social Science) version 21 (Chicago Illinois). Frequency distributions of categorical variables were represented in tables and charts. Mean and standard deviation of continuous variables - age, number of children, duration of breastfeeding including exclusive breastfeeding, age of introduction of complementary feeding and family diet, weight, height and duration on HAART were calculated. Test for statistical significance was carried out using appropriate statistical test - the student t-test for quantitative variables and Chisquare test for qualitative (categorical) variables, as well as multivariate logistic regression analysis and $\mathrm{p}$-value of $\mathrm{p}<$ 0.05 was considered statistically significant.

\section{Results}

A total of 92 HIV positive children comprising 52(56.5\%) males and 40 (43.5\%) females were studied giving a male: female ratio of 1.3:1. Majority (66) of the children (71.7\%) presented at WHO clinical stages 3 and 4, while earlier stages (1 and 2) accounted for 28.3\% (26). Duration on HAART spanned from 1-27 months. Children who were aged more significant than 48 months were about (46.2\%), while a few of them $(9.2 \%)$ were aged 24 months or less. The females were slightly older than the male children, but there was no significant difference in the age distribution of the children. The mean age of the children was $44.5+12.9$ months, while that of the male and female children were $43.9 \pm 13.1$ months and $45.2 \pm 12.6$ months, respectively (See Table 1). The distribution of the children by nutritional status and gender is shown in Table 2. Males were significantly more malnourished than the females (46.2\% and $32.5 \%)$ respectively. Multivariate logistic regression also showed that being a male increased the risk of being underweight $(0 R=2.55$, 95\%CI=1.06-6.16) and stunted (OR=2.67, 95\% CI=1.32-5.40). The relationship between the duration of HAART and nutritional status is shown in Table 3. 
Table 1 Socio-demographic Characteristics of the Children by gender.

\begin{tabular}{|c|c|c|c|c|}
\hline Characteristic & $\begin{array}{l}\text { Male } \\
n=52(\%)\end{array}$ & $\begin{array}{l}\text { Female } \\
n=40(\%)\end{array}$ & $\begin{array}{l}\text { Total } \\
\mathrm{n}=92(\%)\end{array}$ & P-value \\
\hline \multicolumn{5}{|l|}{ Age (in months) } \\
\hline$<24$ & $6(11.5)$ & $3(7.5)$ & $9(9.8)$ & \\
\hline $25-36$ & $12(23.1)$ & $9(22.5)$ & $21(22.8)$ & 0.18 \\
\hline $37-48$ & $9(17.3)$ & $10(25.0)$ & $19(20.7)$ & \\
\hline$>48$ & $25(48.1)$ & $18(45.0)$ & $43(46.7)$ & \\
\hline Mean+SD & $43.9+13.1$ & $45.2+12.6$ & $44.5+12.9$ & \\
\hline \multicolumn{5}{|l|}{ Place of } \\
\hline \multicolumn{5}{|l|}{ Residence } \\
\hline Urban & $35(67.3)$ & $27(67.5)$ & $62(67.4)$ & \\
\hline Rural & $17(32.7)$ & $13(32.5)$ & $30(32.6)$ & 0.81 \\
\hline \multicolumn{5}{|l|}{ Social Class } \\
\hline Low & $39(75.0)$ & $32(80.0)$ & $71(77.2)$ & \\
\hline Middle & $10(19.2)$ & $6(15.0)$ & $16(17.4)$ & 0.35 \\
\hline High & $3(5.8)$ & $2(5.0)$ & $5(5.4)$ & \\
\hline
\end{tabular}

Table 2 Distribution of the children by Nutritional Status and gender

\begin{tabular}{|c|c|c|c|c|}
\hline Malnutrition & $\begin{array}{l}\text { Male } \\
n=52(\%)\end{array}$ & $\begin{array}{l}\text { Female } \\
n=40(\%)\end{array}$ & $\begin{array}{l}\text { Total } \\
\mathrm{n}=92(\%)\end{array}$ & P-value \\
\hline \multicolumn{5}{|l|}{ Wasting } \\
\hline Normal & $46(88.5 \%)$ & $34(84.5)$ & $80(87.0)$ & \\
\hline Wasting & $5(9.6)$ & $5(11.8)$ & $10(10.9)$ & 0.53 \\
\hline Severe Wasting & $1(1.9)$ & $1(3.7)$ & $2(2.1)$ & \\
\hline \multicolumn{5}{|l|}{ Underweight } \\
\hline Overweight & $1(1.9)$ & $0(0.0)$ & $1(1.1)$ & \\
\hline Normal & $41(78.8)$ & $36(90.0)$ & $77(83.7)$ & \\
\hline Underweight & $8(15.4)$ & $3(7.5)$ & $11(11.9)$ & 0.95 \\
\hline Severe underweight & $2(3.8)$ & $1(2.5)$ & $3(3.3)$ & \\
\hline \multicolumn{5}{|l|}{ Stunting } \\
\hline Normal & $34(65.4)$ & $32(80.0)$ & $66(71.7)$ & \\
\hline Stunting & $5(9.6)$ & $5(12.5)$ & $10(10.9)$ & $<0.001$ \\
\hline Severe Stunting & $13(25.0)$ & $3(7.5)$ & $16(17.4)$ & \\
\hline \multicolumn{5}{|l|}{ Overall malnutrition } \\
\hline Normal & $28(53.8)$ & $27(67.5)$ & $55(59.8)$ & 0.02 \\
\hline Under nutrition & $24(46.2)$ & $13(32.5)$ & $37(40.2)$ & \\
\hline
\end{tabular}


Table 3 Relationship between Duration of HAART and Nutritional Status

\begin{tabular}{|c|c|c|c|}
\hline Nutritional Status & $\begin{array}{l}\text { Duration of HAART } \\
\leq 12 \text { months } \\
n=29(\%)\end{array}$ & $\begin{array}{l}>12 \text { months } \\
n=63(\%)\end{array}$ & $\mathrm{P}$-value \\
\hline \multicolumn{4}{|l|}{ Wasting } \\
\hline Normal & $23(79.3)$ & $57(90.5)$ & \\
\hline Wasting & $5(17.2)$ & $5(7.9)$ & 0.02 \\
\hline Severe Wasting & $1(3.4)$ & $1(1.6)$ & \\
\hline \multicolumn{4}{|l|}{ Underweight } \\
\hline Normal & $21(72.4)$ & $57(90.5)$ & \\
\hline Underweight & $6(20.7)$ & $5(7.9)$ & $<0.001$ \\
\hline Severe Underweight & $2(6.9)$ & $1(1.6)$ & \\
\hline \multicolumn{4}{|l|}{ Stunting } \\
\hline Normal & $13(20.2)$ & $53(84.1)$ & \\
\hline Stunting & $5(55.3)$ & $4(6.3)$ & $<0.001$ \\
\hline Severe Stunting & $11(66.2)$ & $6(9.5)$ & \\
\hline
\end{tabular}

\section{Discussion}

Malnutrition is prevalent worldwide, but the impact is felt more in developing countries. Its effect is worsened by HIV/AIDS. Introduction of HAART in the management of HIV has resulted in improvement in the nutritional status of children living with HIV [17-21]. This present study observed a prevalence rate of undernutrition of $40.2 \%$. The prevalence of wasting was $13.0 \%$, underweight and stunting were $15.2 \%$ and $28.3 \%$ respectively, while $17.4 \%$ were severely stunted. This was lower than the prevalence of undernutrition reported by Anigilaje and Olutola [22] in Makurdi, Benue State, which gave prevalence rates of $12.1 \%, 33.5 \%$ and $54.4 \%$ for underweight, wasting and stunting respectively.

A study was done by Anyabolu et al [23] in Ile-Ife, South Western Nigeria also documented higher prevalence rates of $48.6 \%, 58.6 \%$ and $31.4 \%$ for stunting, underweight and wasting respectively. The reason for this disparity is because Anigilaje and Olutola and Anyabolu et al, [23] did their studies among HIV-infected children who were not on HAART. The prevalence rates in this study were also lower, as compared with the estimates from the 2013 NDHS [4], which gave a rate of $37 \%$ for stunting and $21 \%$ for severe stunting. About $18 \%$ of the studied population was wasted, while $29 \%$ were underweight in the NDHS survey. The reason for the lower prevalence rate seen in this study may probably be because the HIV children used in this study were under specialized care, with nutritional rehabilitation as a component of the package. Still, the NDHS survey considered a broader population of under-five children, some of whom may be HIV infected but not on HAART [4]. There is a lack of literature on the prevalence of stunting, wasting and underweight in HIV children on HAART in Nigeria. However, some studies done in other countries have documented higher prevalence rates. A study done in Cameroon among 39 HIV-infected children on HAART recorded a prevalence rate of $51.3 \%, 56.4 \%$ and $20.5 \%$ for stunting, underweight and wasting respectively [24]. Another study in Tanzania documented a rate of $36.6 \%, 22.1 \%$ and $13.6 \%$ for stunting, underweight and wasting respectively on ART-treated HIV children [25]. A study in India reported that malnutrition persists in HIV children even when they are on HAART [26]. The reasons for the disparity in the prevalence rates are not readily available but may be due to the level of care and secondly the prevalence and severity of malnutrition of these children before they were enrolled into HAART and HIV care programs. The height-for-age index is an indicator of linear growth retardation. Children whose height-for-age Zscore was found to be less than minus two standard deviations (-2SD) from the median of the reference population were considered short for age (stunted) and are chronically malnourished, while those with height-for-age Z score less than minus three standard deviations (-3SD) were classified as severely stunted [27, 28].

The weight-for-height index measures body mass in relation to body height or length and describes current nutritional status. Children whose weight-for-age Z-scores were found to be less minus two standard deviations (-2SD) from the median of reference population were considered thin (wasted) and were acutely malnourished. Children whose weightfor-height was less than minus three standards (-3SD) were considered to be severely wasted $[27,28]$. 
Weight-for-age is a composite index of height-for-age and weight-for-height. It takes into account both acute and chronic malnutrition. Children whose weight-for-age Z-score was below minus two standard deviations (-2SD) from the median of the reference population were classified as underweight. Children whose weight-for-age was below minus three standard deviations (-3SD) from the median of the reference population were considered as severely underweight [27, 28].

Prevalence of stunting was also seen to be consistently higher than underweight and wasting. This is expected because stunting is a marker of longstanding nutritional deprivation. It was also noted in this present study that males were significantly more malnourished than the females (46.2\% and 32.5\%) respectively. Multivariate logistic regression also showed that being a male increased the risk of being underweight $(\mathrm{OR}=2.55,95 \% \mathrm{CI}=1.06-6.16)$ and stunted $(\mathrm{OR}=2.67$, $95 \% \mathrm{CI}=1.32-5.40$ ). This could be explained in part by the fact that male children are usually more active and require more calories than females. Awogbenja and Ugwuona [29] in the Nasarawa State of Nigeria documented that females were less likely to be underweight in their study (AOR=0.292, 95\%CI=0.103-0.820). A study in Kenya by Mishra et al [30] documented that males were more likely to be stunted. Another survey by Lwanga et al [31] in Uganda documented that males had a 4-fold risk of being stunted. Unlike in this study, Mohd et al[32] reported a higher prevalence of stunting among females in a study of 95 children on HAART in Malaysia, 39.0\% and 33.3\% females and males, respectively. Kumar et al [33] documented that stunting was commoner in girls than boys in India, $63.3 \%$ and $44.9 \%$ respectively. Woldie et al [34] in Southern Ethiopia documented that there was a slight increase in the prevalence of stunting (51.7\%) in males than females (48.9\%) though not statistically significant $(p=0.965)$. Padmapriyadarsini et al[35] in India documented that rates of stunting were similar in both male and female. The reasons for these differences are not readily available, but one may infer that stunting could occur irrespective of gender.

The longer duration on HAART was shown to significantly improve the nutritional status of children in this study. Children who had received HAART for more than twelve months were less likely to be wasted $(X 2=7.64, p=0.002)$, underweight $(\mathrm{X} 2=21.60, \mathrm{p}<0.001)$ or stunted $(\mathrm{X} 2=61.42, \mathrm{p}<0.001)$. This was further bolstered by the fact that logistic regression showed that the duration of HAART is a significant predictor of wasting $(\mathrm{OR}=3.06,95 \% \mathrm{CI}=1.45-8.06)$. This result is expected because with the introduction of HAART in the management of HIV, the viral load starts decreasing, CD4 starts increasing, and metabolic rate following infectious processes starts reducing, with subsequent improvement in the anthropometry of these children. A similar study by Ezeonwu et al [36], in Enugu South-East Nigeria, documented that children who were malnourished in their study had a shorter duration of HAART treatment than the wellnourished. Sunguya et al [37] in Tanzania compared HIV children on HAART for a duration of 6 months, 6 - 12 months and $>12$ months and documented that those that had ARV for $>12$ months were less likely to be underweight and wasted. Lodha and Kabra [38] in a longitudinal study in India, involving HIV children commenced on HAART, documented that there was a statistically significant improvement in nutritional status over one year on HAART as against 6 months in underweight, wasting and stunting. Early commencement of HAART once the diagnosis of HIV is confirmed in children aids improvement in their nutritional status and hence reduce morbidity and mortality.

This study has a number of limitations. The cross-sectional design of this study limits the conclusion on the cause and effect relationship between associated factors of malnutrition.

\section{Conclusion}

It is concluded that malnutrition is still a problem for children living with HIV, even though on HAART. The duration on HAART is significantly associated with better nutritional status. There is a need for HIV positive mothers to begin nutrition counseling during pregnancy so that they can make well-informed choices on how to feed their babies. Also, the implementation of the already existing infant and young children feeding policies is advised. Implementation of growth monitoring should be sustained as part of the care of HIV patients. This will help to detect dwindling in anthropometric indices and institute appropriate intervention early enough.

\section{Compliance with ethical standards}

\section{Acknowledgement}

The current work took great effort from all colleagues who work in the Nnamdi Azikiwe University Teaching Hospital, who kindly participated in the case management and patient follow up. Great thanks are due to all who shared and helped to put this work in its final form. 


\section{Disclosure of conflict of interest}

The authors declare no conflicts of interests.

\section{Statement of Ethical approval}

The study protocol was approved by the by Nnamdi Azikiwe University Teaching Hospital (NAUTH) Ethics committee with approval number of NAUTH/CS/VOL.3/100.

\section{Authors' contributions}

All the authors participated in the research.

\section{Statement of informed consent}

A written informed consent was obtained from all individual participants included in the study.

\section{References}

[1] Akuyam SA A review of some metabolic changes in protein-energy malnutrition. Niger Postgrad Med J. 2007 Jun; 14(2):155-62. PMID: 17599117.

[2] James WP. From treating childhood malnutrition to public health nutrition. Annals of Nutrition and Metabolism. 2018; 72(3):202-9.https://doi.org/10.1159/000487273

[3] Rodríguez L, Cervantes E, Ortiz R. Malnutrition and gastrointestinal and respiratory infections in children: a public health problem. Int J Environ Res Public Health. 2011 Apr; 8(4):1174-205. doi: 10.3390/ijerph8041174.

[4] Akombi BJ, Agho KE, Renzaho AM, Hall JJ, Merom DR. Trends in socioeconomic inequalities in child undernutrition: Evidence from Nigeria Demographic and Health Survey (2003 - 2013). PLoS One. 2019 Feb 7; 14(2):e0211883. doi: 10.1371/journal.pone.0211883.

[5] Ugochukwu EF, Egbuonu I. Comparative use of anthropometric indices in the detection of malnutrition among nursery school children in Nnewi, Nigeria. Tropical Journal of Medical Research 2009; 13(1); 8-14.

[6] Suttman U, Ockenga J, Sellberg O, Hoogestraat L, Deicher H, Muller MJ. Incidence and prognostic value of malnutrion and wasting in HIV infected outpatients. J Acquir Immune Defic Syndrome Human Retroviral 1995; 8:239-46.

[7] Institute of Medicine (US) Committee on Envisioning a Strategy for the Long-Term Burden of HIV/AIDS: African Needs and U.S. Interests. Preparing for the Future of HIV/AIDS in Africa: A Shared Responsibility. Washington (DC): National Academies Press (US); 2011. 4. The Burden of HIV/AIDS: Implications for African States and Societies. Available from: https://www.ncbi.nlm.nih.gov/books/NBK209743/

[8] Knox FA, Zanfote-Sanders M, Fields-Gardner C, Moen K, Johasen D, Paton N. Assessment of Nutritional status, body composition and HIV associated morphologic changes. Clin Infect Dis 2003; 36: S63-68.

[9] Ivers CL, Cullen AK, Freedberg AK, Block S, Coates J, Webb P. HIV/AIDS, undernutrition and food insecurity. Clin Infect Dis 2009; 49:1096-1102.

[10] Khuwaja S, Selwyn BJ, Shah SM. Prevalence and correlates of stunting among primary school children in rural areas of Southern Pakistan. Journal of Tropical Pediatrics 2005; 51(2): 72-77. https://doi.org/10.1093/tropej/fmh067.

[11] Ejiofor OS, Ajunwa OM, Ezeudu CE, Emechebe GO, Okeke KN, Ifezulike CC, Ekejindu IM, Okoyeh JN, Osuala EO, Oli AN. The Bacteriology and Its Virulence Factors in Neonatal Infections: Threats to Child Survival Strategies. J Pathog. 2018 Jul 2; 2018:4801247. doi: 10.1155/2018/4801247.

[12] UNAIDS. Report on the global AIDS epidemic 2013; 46-59

[13] Bertozzi S, Padian NS, Wegbreit J, et al. HIV/AIDS Prevention and Treatment. In: Jamison DT, Breman JG, Measham AR, et al., editors. Disease Control Priorities in Developing Countries. 2nd edition. Washington (DC): The International Bank for Reconstruction and Development / The World Bank; 2006. Chapter 18. Available from: https://www.ncbi.nlm.nih.gov/books/NBK11782/ Co-published by Oxford University Press, New York.

[14] UNAIDS. A new report on joint United Nations Programme on HIV/AIDSS 2011; 1-52. 
[15] Chen Q, Kong Y, Gao W, Mo L. Effects of Socioeconomic Status, Parent-Child Relationship, and Learning Motivation on Reading Ability. Front Psychol. 2018 Jul 25; 9:1297. doi: 10.3389/fpsyg.2018.01297. PMID: 30090082; PMCID: PMC6068389..

[16] WHO Multicentre Growth Reference Study Group: WHO Child Growth Standards: L/H-for-age, weight-for-age, weight-for-length/height-for-age and body mass index for age. Methods and development. Geneva, World Health Organization, 2006. http://www.who.int/childgrowth/standard/technicalreport/en/index.html.

[17] Verwee IG, Van Rossum AM, Hartwig NG, Wolfs TF, Scherpblerm HJ, De groot R. Treatment with HAART in HIV type-1 infected children is associated with sustained effect on growth. Paediatr 2002; 109: E25.

[18] Rauen E. Early initiation of HAART in children HIV infection and severe malnutrition. Master's thesis submitted to the Charite. Universitatmedizin Berlin. Frele Universitat and Humboldt Universitat Berlin in partial fulfillment of the requirement for the award of a Master of Science degree in international Health. August, 2009; 1-77.

[19] Banerjee T Pensi T, Banerjee D, Grover G Impact of HAART on survival, weight gain, and resting energy expenditure in HIV-I infected children in India. Ann Trop Paediatr 2010; 30:27-37.

[20] Miller TL. Nutritional aspects of HIV-infected children receiving highly active antiretroviral therapy. AIDS 2003; 17: S130-140.

[21] Ebonyi AO, Oguche S, Dablets E, Sumi B, Yukubu E, Sagay AS, Effect of HAART on growth parameter and absolute CDE count among HIV-infected children in a rural community of central Nigeria. Nig J Paediatr 2014; 41:1-6.

[22] Anigilaje EA, Olutola A. Prevalence and risk factors of anemia among human immunodeficiency virus infected antiretroviral therapy naïve children in Makurdi, Nigeria: A retrospective study. Journal of AIDS and HIV Research. 2014; 6(6):128-137

[23] Anyabolu HC, Adejuyigbe EA, Adeodu 00. Serum Micronutrient Status of HAART-Naïve, HIV Infected Children in South Western Nigeria: A Case Controlled Study. AIDS Res Treat. 2014; 2014:351043. doi: $10.1155 / 2014 / 351043$.

[24] Penda CI, Moukoko ECE, Nolla NP, Evindi NOA, Ndombo PK. Malnutrition among HIV infected children under 5 years of age at the Laquintinie hospital Douala, Cameroon. Pan Afr Med J. 2018 May 31; 30:91. doi: 10.11604/pamj.2018.30.91.15832. PMID: 30344875; PMCID: PMC6191246.

[25] Sunguya BF, Poudel KC, Otsuka K, Yasuoka J, Mlunde LB, Urassa DP, Mkopi NP, Jimba M. Undernutrition among HIV-positive children in Dar es Salaam, Tanzania: antiretroviral therapy alone is not enough. BMC Public Health. 2011 Nov 16; 11:869. doi: 10.1186/1471-2458-11-869.

[26] Swetha GK, Hemalatha R, Prasad UV, Murali V, Damayanti K, Bhaskar V. Health \& nutritional status of HIV infected children in Hyderabad, India. Indian J Med Res. 2015 Jan; 141(1):46-54. doi: 10.4103/0971-5916.154494.

[27] National Population Commission and ICF International. 2014. Nigeria demographic and Health Survey 2013. Abuja, Nigeria, and Rockville, Maryland, USA: NPC and ICF International. 175-197.

[28] National Population Commission (NPC) (Nigeria) and ORC macro Nigeria Demographic and Health Survey EdData Survey 2004, Calverton, Maryland: National Population Commission and ORC macro. 2005; 3-40.

[29] Awogbenja MD, Ugwuona FU. Feeding practices and nutritional status of under-five children in Nasarawa State, Nigeria. PAT 2010; 6:23-35.

[30] Mishra V, Arnold F, Otieno F, Cross A, Hong R. Education and nutritional status of orphans and children of HIVinfected parents in Kenya. Aids Educ and Prevention.2007; 19-30.

[31] Lwanga F, Wanyenze RK, Matovu JKB, Orach CG. Food security and nutritional status of children residing in sugarcane growing communities of east central Uganda: a cross-sectional study. J of Food Security 2015; 3:34-9

[32] Mohd NM, Yeo J, Huang MS, Kamarul AM, Koh MT, Khor GL. Nutritional status of children living with HIV and receiving antiretroviral medications in Kiang valley Malaysia. Malays Nutr 2011; 17:19-30.

[33] Kumar D, Goel KN, Mittal C, Misra P. Influence of infant feeding on the nutritional status of under-five children. Indian J Paediatr 2006; 73:417-421.

[34] Woldie H, Kebede Y, Tariku A. Malnutrition in Malaysia children. Malays J Paediatr 2004; 5:44-46.

[35] Padmapriyadarsina C, Paoranagangadevi N, Chandrasekaran K, Subramanyan S, thiruvalluvan C, Bhavani PK et al. Prevalence of underweight, stunting and waisting among children infected with Human Immunodeficiency Virus in south India. http://www.biomedcentral.com/1471-2431/9/37, 
[36] Ezeonwu BU, Ikefuna AN, Oguonu T Okafor HU. Prevalence of haematological abnormalities and malnutrition in HIV-infected under-five children in Enugu. Nig J of ClinPract 2014; 17:333-308.

[37] Sunguya BF, Poudel KC, Otsuka K, Yasuoka J, Miunde LB, Urassa DP et al. Undernutrition among HIV-positive children in Dar es Salaam, Tanzania: antiretroviral therapy alone is not enough. BMC public Health 2011; 11:869.

[38] Lodha R, Kabra SK. Health \& nutritional status of HIV infected children. Indian J Med Res. 2015 Jan; 141(1):10-2. doi: 10.4103/0971-5916.154486. 